\title{
Comparison of assimilation of fermentable sugars in wort by the immobilized yeast in alginate gel and the free yeast in high gravity brewing
}

- Tran Quoc Hien

- Le Van Viet Man

University of Technology, VNU-HCM

- Hoang Kim Anh

The Institute of Tropical Biology

(Manuscript Received on January 21 ${ }^{\text {st }}$, 2013, Manuscript Revised October $18^{\text {th }}$, 2013)

\begin{abstract}
:
In this work, the assimilation of different fermentable sugars by the immobilized yeast in alginate gel and the free yeast under high gravity brewing conditions was investigated and compared. Both immobilized and free yeast utilized glucose, fructose, sucrose and maltose in wort from the beginning of the fermentation. Maltotriose uptake of the fixed
\end{abstract}

cells was also observed during the first hours of fermentation while the free cells only started assimilating maltotriose after the first $48 \mathrm{~h}$. High osmotic pressure at the start of the fermentation changed cellular morphology and that could decelerate the maltotriose uptake of the free yeast.

Key words: fermentation kinetics, high gravity brewing, immobilization, morphology, ccharomyces cerevisiae

\section{INTRODUCTION}

Wort contains different sugars, including fructose, glucose, sucrose, maltose and maltotriose as well as other carbohydrates, in varying concentrations [2,7]. During the fermentation, the utilization of wort carbohydrates, especially the utilization of maltose, glucose and fructose by the yeast is a major determinant of fermentation efficiency and final beer quality. According to Boulton et al., sucrose was utilized first and the resultant hydrolysis causes a transient increase in the concentration of fructose. Fructose and glucose

were taken up more and less simultaneously. Completion of assimilation of glucose was followed by utilization of maltose, the major wort sugar. Maltotriose was utilized last after all utilization of maltose [2]. Meanwhile, according to D'Amore et al., when glucose and fructose are fermented separately, both sugars are utilized at similar rates. However, when fermentations are conducted in media containing an equal concentration of glucose and fructose, glucose is utilized at approximately twice the rate of fructose. The preferential utilization of glucose 
also occurred when sucrose, which was first rapidly hydrolyzed into glucose and fructose by the enzyme invertase, was employed as a substrate [3].

Phaweni et al. stated that the sequential uptake of sugars in all-malt wort by S. cerevisiae 2036 was as follow: sucrose, glucose, fructose, maltose and maltotriose. This result was also valid in the fermentation if maltose was used as the total wort adjunct. Meanwhile, when glucose was used as the total adjunct, glucose utilization was retarded and consequently fructose utilization was blocked [7].

During the last decades, high gravity brewing has been widely applied to brewing industry. High gravity brewing involves preparation and fermentation of wort with a specific gravity higher than $12^{\circ}$ Plato. By increasing the wort specific gravity, the higher levels of the ethanol per given plant capacity can be achieved and substantial savings can be attained by the brewer; the plant efficiency and capacity are increased; labour, energy and capital costs are reduced [6]. On the other hand, application of immobilized yeast to brewing has been considered as a very promising technology. The use of immobilized yeast in the fermentation process and their potential advantages over the free yeast systems have been widely investigated and reviewed [4].

The assimilation of fermentable sugars by immobilized and free yeast in high gravity brewing has not been clearly considered. The objective of this work was to investigate and compare the uptake of the fermentable sugars in wort by the immobilized yeast in alginate gel and the free yeast in high gravity brewing.

\section{MATERIALS AND METHODS}

\subsection{Materials}

Saccharomyces cerevisiae (lager strain) used in this study was supplied by Tien Giang Foster Company.
Sodium alginate was supplied by Biotechnology Center, Nha Trang University. The ratio of mannuronic acid to guluronic acid was 1.2 . The viscosity of $2 \%$ alginate solution at $25^{\circ} \mathrm{C}$ was $423.6 \mathrm{cp}$.

Barley malt was supplied by Duong Malt Company; the extraction yield was $80 \%$. High maltose syrup supplied by Bibica Company was used as adjunct; the dextrose equivalent was approximately 42 .

\subsection{Experimental methods \\ Preparation of high gravity wort}

The wort was prepared from barley malt using conventional brewing techniques [2]. In this study, the $24^{\circ} \mathrm{Pt}$ wort was used. The extract of $24^{\circ} \mathrm{Pt}$ wort was originated from $70 \%$ barley malt and $30 \%$ maltose syrup.

\section{Inoculum preparation}

Inoculum was prepared from $8 \%(\mathrm{w} / \mathrm{w})$ malt wort medium according to the procedure previously described elsewhere [11].

\section{Yeast immobilization in alginate gel}

A volume of yeast suspension $(1.0 \times 108 \mathrm{cell} / \mathrm{mL})$ was added to an equal volume of sodium alginate solution $(50 \mathrm{~g} / \mathrm{L})$ and homogenized. This mixture was then dropped into a $3 \%(\mathrm{w} / \mathrm{v}) \mathrm{CaCl} 2$ solution for formation of calcium alginate gel beads. The cell concentration in the gel bead was approximately $5.0 \times 107 \mathrm{cell} / \mathrm{cm} 3$. The residence time of the gel beads in $\mathrm{CaCl} 2$ solution was $4 \mathrm{~h}$ at $4 \mathrm{oC}$ for increasing the gel strength. The gel beads were then washed with sterile water [11].

Beer fermentation by immobilized yeast in alginate gel

Batch fermentation was carried out in $2.5 \mathrm{~L}$ stainless steel fermenters containing $2.0 \mathrm{~L}$ of $24^{\circ} \mathrm{Pt}$ wort without stirring. The fermentation temperature was $17^{\circ} \mathrm{C}$. The inoculation rate was $1.0 \times 10^{6}$ cells $/ \mathrm{mL}$ of wort. The fermentation was considered as completed when the degree of

\section{Trang94}


attenuation reached $75 \%$. The degree of attenuation was calculated by the reducing sugar content in the initial wort and in the green beer [6].

Control sample was simultaneously performed with the free yeast under the same conditions.

Change in morphology of yeast cells under high osmotic stress

The immobilized and free yeast cells were soaked in $24 \%$ (w/v) sorbitol solution at ambient temperature for $30 \mathrm{~min}$. The cells were then removed for morphological observation under scanned electronic microscope (SEM).

\subsection{Analytical methods}

Fermentable sugars were determined by highperformance liquid chromatography (Shimadzu corporation) using a detector RID-10A. A RNMcarbohydrate $\mathrm{Na}^{+}$column $(7.8 \times 300)$ at $65^{\circ} \mathrm{C}$ was used with $\mathrm{H}_{2} \mathrm{O}$ as eluant. The flow rate was $1 \mathrm{~mL} / \mathrm{min}$, and the injection volume was $20 \mu \mathrm{L}$ [7].

SEM was used for morphological observation of yeast cells. The immobilized and free cells were fixed by $1 \%$ glutaraldehyde in cocadylic buffer, dehydrated and prepared for observation under SEM (JEOL Co., JSM-7401F) according to a standard procedure described by Van Neerven et al. [12].

\subsection{Statistical analysis}

All experiments were performed in triplicate. Mean values were considered significantly different when $\mathrm{P}<0.05$. Analysis of variance was performed using the software Statgraphics plus (version 3.2, StatPoint technologies, Inc., USA).

\section{RESULTS AND DISCUSSION}

The kinetics of sugar assimilation of the immobilized yeast in alginate gel and the free yeast are presented in Figure 1 and 2, respectively.

\section{Sucrose uptake}

The wort used in this study had low sucrose level $(3.5 \mathrm{~g} / \mathrm{L})$. After the first $12 \mathrm{~h}$ of fermentation, the sucrose concentration in the immobilized and free yeast cultures remained $7.8 \%$ and $22.9 \%$ of that in the initial wort, respectively. Thus, the immobilized yeast assimilated sucrose faster than the free yeast during the first $12 \mathrm{~h}$ of fermentation. Patel et al. suggested that sucrose hydrolyzed into glucose and fructose by the enzyme invertase on the cytoplasmic membrane of yeast and the yeast easily assimilated the substrates [5]. Figure 1 and 2 shows that after $24 \mathrm{~h}$ of fermentation, the sucrose was disappeared from the wort in both cases.

\section{Glucose uptake}

The glucose concentration in the free yeast culture was nearly unchanged during the first 24 $\mathrm{h}$ of fermentation. During this period, the sucrose was completely hydrolyzed but the glucose level in the fermented wort did not increase further. We suggested that the hydrolytic rate of sucrose was similar to the uptake rate of glucose by the free yeast during the first $24 \mathrm{~h}$ of fermentation. D'Amore et al. also observed the same rule in $16^{\circ} \mathrm{Pt}$ wort fermentation with the free yeast [3]. In our study after $24 \mathrm{~h}$ fermentation, the glucose concentration in the free yeast culture started decreasing; and the glucose was exhausted after $72 \mathrm{~h}$. For the immobilized yeast, the glucose content in wort gradually reduced during the first hours of fermentation although the hydrolysis of sucrose occurred during this period. After $48 \mathrm{~h}$, the glucose in the immobilized yeast culture was disappeared. Thus, the alginate gel increased the glucose uptake rate of the immobilized yeast. The assimilation time of glucose by the fixed yeast in alginate gel was $24 \mathrm{~h}$ shorter than that by the free yeast. 


\section{Fructose uptake}

The fructose level in the two cultures was unchanged during the first $12 \mathrm{~h}$ of fermentation. Due to sucrose hydrolysis during this period, we concluded that both immobilized and free yeast utilized fructose from the beginning of the fermentation. From the 12th to the 24th hour, slight increase in fructose content was observed in the free yeast culture whereas the fructose concentration in the immobilized yeast culture was reduced. Consequently, the immobilized cells in alginate gel utilized fructose faster than the free cells. Disappearance of fructose from the wort fermented by the fixed and the free yeast was observed after $84 \mathrm{~h}$ and $108 \mathrm{~h}$, respectively. It should be noted that fructose uptake was significantly slower than glucose uptake by both immobilized and free yeast in high gravity brewing.

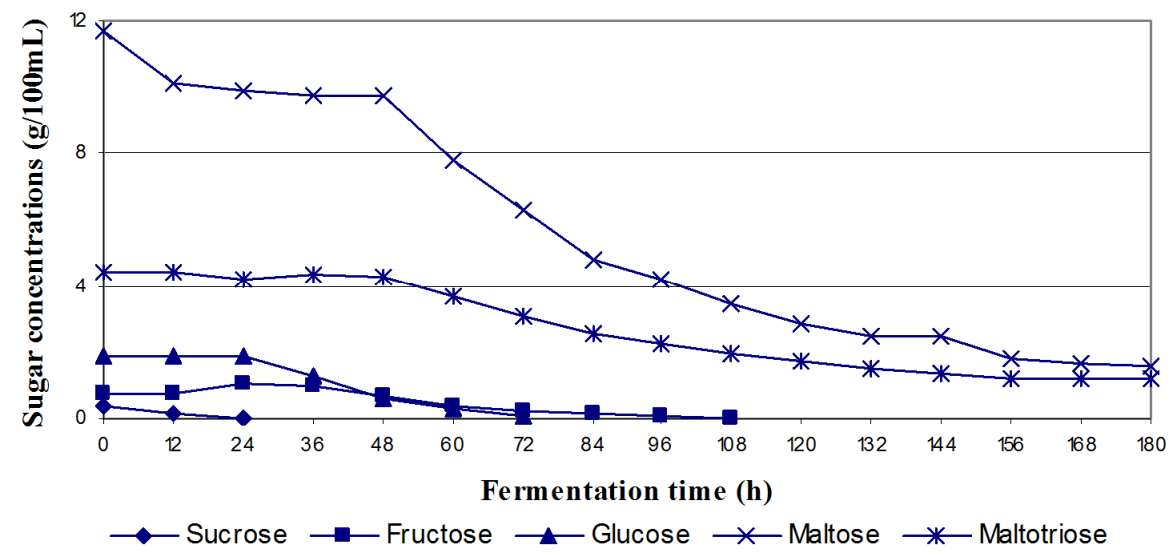

Figure 1. Assimilation of fermentable sugars of the free yeast during the primary fermentation in high gravity brewing (The $24^{\circ} \mathrm{Pt}$ wort extract was originated from $70 \%$ barley malt and $30 \%$ maltose syrup)

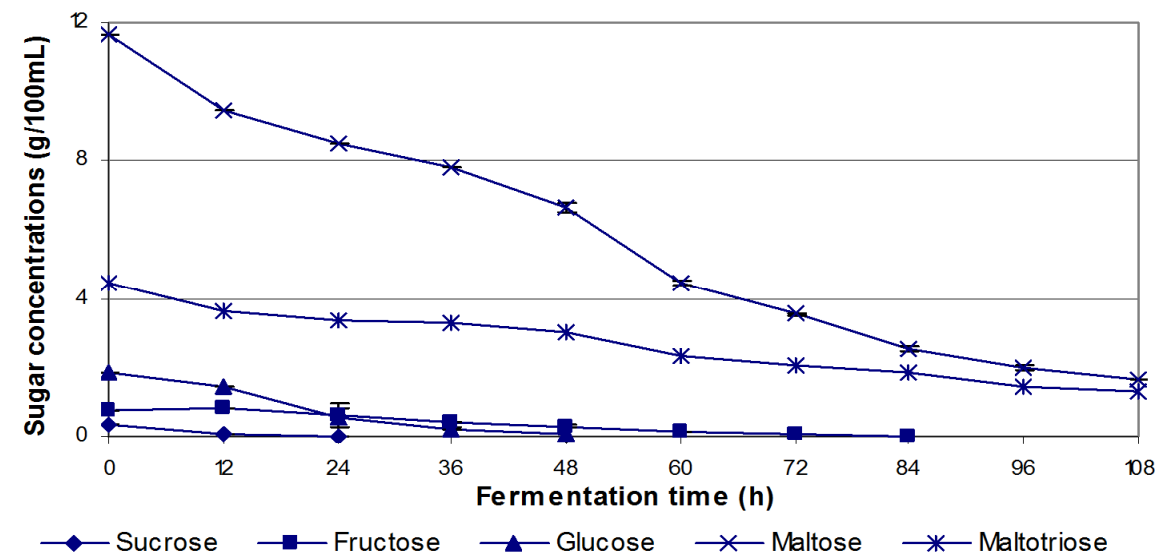

Figure 2. Assimilation of fermentable sugars of the immobilized yeast during the primary fermentation in high gravity brewing (The $24^{\circ} \mathrm{Pt}$ wort extract was originated from $70 \%$ barley malt and $30 \%$ maltose syrup)

\section{Trang 96}




\section{Maltose uptake}

Maltose is a main disaccharide in wort. Both immobilized and free yeast used maltose from the first hours of fermentation. After $48 \mathrm{~h}$, the maltose content in wort remained $85.5 \%$ and $54.2 \%$ of initial level for the immobilized and free yeast culture, respectively. The immobilized yeast in alginate gel assimilated maltose faster than the free yeast.

\section{Maltotriose uptake}

Some researchers suggested that in conventional brewing, yeast starts assimilating maltotriose when maltose is nearly disappeared from wort [9]. Conversely, other researchers found that yeast could utilize maltotriose when maltose concentration in the culture is still high $[5,7]$.

Figure 2 shows that the free yeast did not utilize maltotriose during the first $48 \mathrm{~h}$ of fermentation. Similar observation was also reported by Boulton et al. who fermented an ale wort of original gravity of 1.040. The free yeast started assimilating maltotriose after $48 \mathrm{~h}$ of fermentation [2]. Many researchers affirmed that transport of maltotriose across the cytoplasmic membrane of the yeast $S$. cerevisiae is performed by permease AGT1 [1]. Boulton et al. suggested that high osmotic pressure could inhibit the activity of the permease participating in maltotriose transport [2].

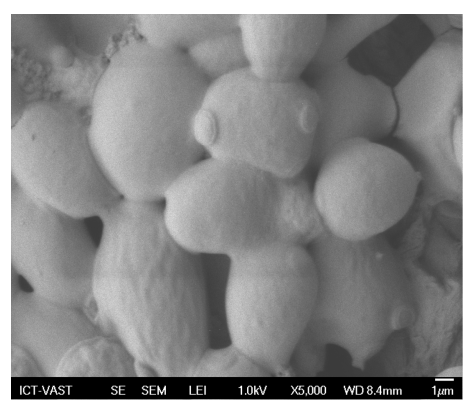

A1

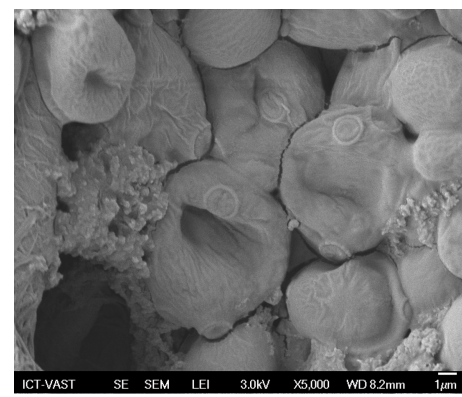

A2

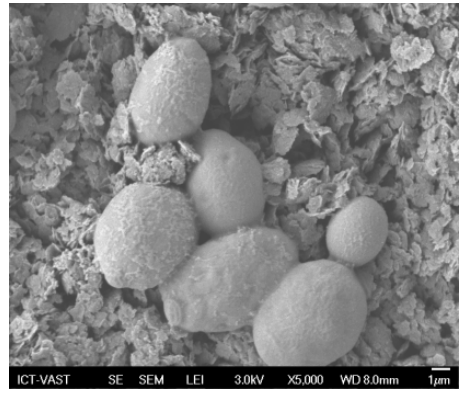

B1

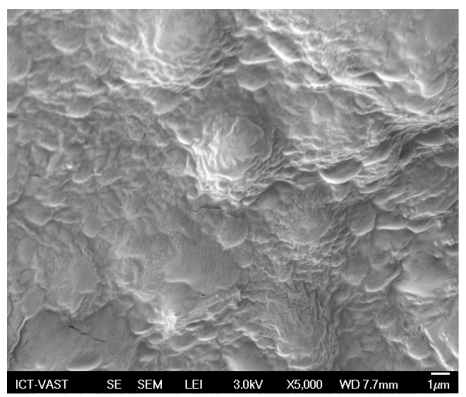

B2

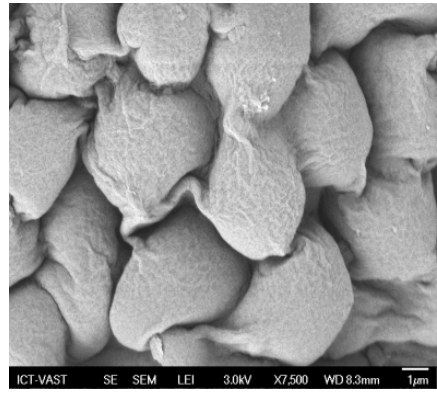

$\mathrm{C} 1$

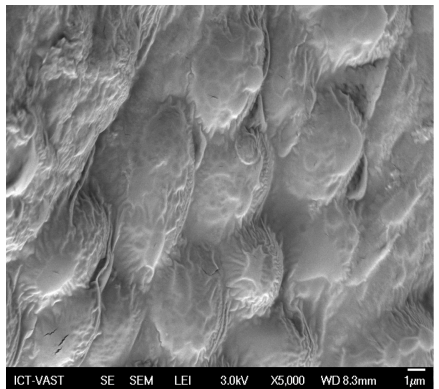

$\mathrm{C} 2$

Figure 3. Images of the free yeast and immobilized in calcium alginate gel by SEM. $\left(A_{1}\right)\left(B_{1}\right)$ and $\left(C_{1}\right)$ the free yeast, the external and internal surface of the gel beads of control samples; $\left(A_{2}\right)\left(B_{2}\right)$ and $\left(C_{2}\right)$ the free yeast, the external and internal surface of the gel bead were exposed to $24^{\circ} \mathrm{Pt}$ sorbitol for 30 minutes. 
Figure 1 reveals an interesting result: maltotriose was used by the immobilized yeast from the beginning of the fermentation. We believed that the immobilized cells were protected by the alginate gel against high osmotic stress in high gravity brewing. As a consequence, the activity of permease AGT1 in the immobilized cells was not inhibited. For this reason, maltotriose uptake by the immobilized yeast in alginate gel was observed from the first fermenting hours. However, the maltotriose uptake rate was significantly slower than maltose uptake rate for both immobilized and free yeast.

To verify the protection role of alginate gel for the immobilized yeast against high osmotic stress, the morphology of the fixed and free yeast was observed and compared. Figure 3A1, 3B1 and $3 \mathrm{C} 1$ show the free yeast, the yeast on the external surface of the gel beads and the yeast at the center of the gel beads, respectively before being exposed to the sorbitol solution. In three cases, yeast cells had oval shape with smooth surface; and the cell morphology was nearly similar. However after $30 \mathrm{~min}$ exposure to $24 \%$ (w/v) sorbitol solution, the free yeast cells were shrunk; crenation and invagination were clearly observed on surface of the yeast cells (Figure $3 \mathrm{~A} 2$ ). On the contrary, Figure 3B2 and 3C2 show that the yeast cells fixed on the external surface of the gel beads and the yeast cells included in the center of the gel beads did not change in morphology. The yeast cells in Figure 3B2 was not clearly visible due to sorbitol adsorption on the outer surface of the gel beads.

Difference in cell morphology between the immobilized and free yeast under high osmotic stress confirms the previous observation of Boulton \& et al. who stated that high osmotic pressure inhibited maltotriose transport of ATG1 permease in the cytoplasmic membrane of $S$. cerevisiae [2]. As a consequence, the free yeast did not use maltotriose during the first period of the fermentation in high gravity brewing. Previously, Pratt L. et al. proved that high osmotic stress caused by $20 \%$ (w/v) sorbitol solution changed the morphology of free yeast cells [8].

\section{CONCLUSION}

For the yeast strain used in this study, the free and immobilized cells assimilated glucose, fructose, sucrose and maltose in wort from the first hours of fermentation. In addition, immobilization of yeast in alginate gel protected the cells against high osmotic stress and the immobilized yeast assimilated maltotriose from the beginning of fermentation while the free yeast started using maltotriose after $48 \mathrm{~h}$ fermentation. In high gravity brewing, the immobilized yeast in alginate gel assimilated fermentable sugars in wort always faster than the free yeast.

\section{Trang98}




\section{So sánh khả năng lên men các loại đường trong dịch nha bởi nấm men cố định trong gel alginate và nấm men tự do trong quá trình lên men bia nồng độ cao}

- Trần Quốc Hiền

- Lê Văn Việt Mẫn

Trường Đại học Bách khoa, ĐHQG-HCM

- Hoàng Kim Anh

Viện Sinh học nhiệt đới

\section{TÓM TÁT:}

Trong nghiên cứu này, chúng tôi khảo sát và so sánh khả năng lên men các loại đường trong dịch nha bởi nấm men cố định trong gel alginate và nấm men tự do trong quá trình lên men bia nồng độ cao. Cả nấm men cố định và tự do đều lên men glucose, fructose, sucrose and maltose trong dich nha ngay từ thời điểm bắt đầu quá trình lên men.

\section{REFERENCES}

[1]. Alves, S.L.; Herberts, R.A.; Hollatz, C.; Trichez, D., Miletti, L.C.; de Araujo, P.S.; Stambuk, B.U. Molecular analysis of maltotriose active transport and fermentation by Saccharomyces cerevisiae reveals a determinant role for the AGT1 permease. Appl. Environ. Microbiol. 74 (5), 1494-1501 (2008)

[2]. Boulton, C. and Quain, D. Brewing yeast and fermentation. Blackwell Science, Oxford (2001)

[3]. D'Amore T.; Russell I.; Stewart, G.G. Sugar utilization by yeast during fermentation. J. Ind. Microbiol. 4 (4), 315324 (1989)
Nấm men cố định cũng lên men maltotriose từ khi quá trình lên men bắt đầu, trong khi đó nấm men tự do bắt đầu lên men maltotriose từ giờ lên men thứ 48. Áp suất thẩm thấu cao vào đầu quá trình lên men đã làm thay đổi hình thái tế bào nấm men tự do và điều đó đã làm cho khả năng lên men maltotriose của nấm men bị trễ hơn.

[4]. Kourkoutas, Y.; Bekatorou, A.; Banat, I. M.; Marchant, R.; Koutinas, A. A. Immobilization technologies and support materials suitable in alcohol beverages production: A review. Food Microbiol. 21 (4), 377-397 (2004)

[5]. Patel G.B. and Ingledew W.M. Trends in wort carbohydrate utilization, Appl. Microbiol. 26 (3), 349-353 (1973)

[6]. Patkova, J.; Smogrovicova, D.; Domeny, Z.; Bafrncova, P. Very high gravity wort fermentation by immobilized yeast. Biotechnol. Lett. 22 (14), 1173-1177 (2000) 
[7]. Phaweni, M.; O'Connor-Cox, E. S. C.; Pickerell, A.T.W.; Axcell, B.C. Influence of adjunct carbohydrate spectrum on the fermentative activity of a brewing strain of Saccharomyces cerevisiae. J. Am. Soc. Brew. Chem. 51 (1), 10-15 (1993)

[8]. Pratt P.L.; Bryce J.H.; Stewart G.G. The effects of osmotic pressure and ethanol on yeast viability and morphology. J. Inst. Brew. 109 (3), 218-228 (2003)

[9]. Rautio J.; Londesborough, J. Maltose transport by brewer's yeasts in brewer's wort. J. Inst. Brew. 109 (3), 251-261 (2003)

[10]. Silva, D.P.; Brankyik, T.; Dragone, G.; Vicente, A.A.; Teixeira, J.A.; Silva, J. B.A. High gravity batch and continuous processes for beer production: Evaluation of fermentation performance and beer quality. Chem. Papers 62 (1), 34-41 (2008)

[11]. Tran, Q.H.; Le, V.V.M.; Hoang, K.A. Influence of yeast and alginate concentrations in alginate gel beads on the fermentation characteristics of immobilized yeast in high gravity brewing. The $4^{\text {th }}$ National Scientific Conference on Biochemistry and Molecular Biology for Agriculture, Biology, Medicine and Food Industry, Hanoi, p.294-297 (2008b)

[12]. Van Neerven, A.R.W.; Wijffels, R.; Zehnder, A.J.B. Scanning electron microscopy of immobilized bacteria in gel beads, a comparative study of fixation methods. J. Microbiol. Methods 11 (3-4), 157-168 (1990) 